\title{
Venäjän
}

\section{varhaiskasvatusalan haasteet ja kehitysnäkymät}

Jelena Kolesnikova

Venäjän varhaiskasvatusala on kohdannut viime aikoina lukuisia ongelmia, jotka vaikuttavat olennaisesti varhaiskasvatuksen ammattilaisten arvostukseen. Neuvostoajalle ominainen työllisyyden ja tulojen vakaus sekä mahdollisuus saada maksutta tärkeimmät yhteiskunnan palvelut (kuten terveydenhoito, koulutus ja asunto) tekivät varhaiskasvatusalalla työskentelemisen houkuttelevaksi ja tukivat ammatin sosioekonomista asemaa yhteiskunnassa. Yhteiskuntarakenteen muutos toi mukanaan Venäjän työväestölle ennestään tuntemattomia ilmiöitä kuten työttömyyden, pimeän työn ja tuloerojen kärjistymisen. Valtiollinen varhaiskasvatus koki 1990-luvun loppupuolella suuria muutoksia, kun käytännöllisesti katsoen puolet suuryritysten ja virastojen omistuksessa olleista varhaiskasvatuslaitoksista lakkautettiin siksi, että ne koettiin liian suureksi ja ylimääräiseksi taloudelliseksi rasitteeksi. Tämän seurauksena myös kasvatus- ja opetusalan henkilöstö supistui merkittävästi. Varhaiskasvatuksen työntekijärakenne on muuttunut, ja tätä nykyä suurin osa alan työntekijöistä on joko saavuttanut eläkeiän tai lähestyy sitä. Ongelmien kasautuessa valtiovalta on joutunut ottamaan kantaa varhaiskasvatuksen tilanteeseen, ja vuodesta 2012 lähtien onkin tehty lukuisia alaa koskevia uudelleenjärjestelyjä. Nämä uudistukset ovat koskeneet varhaiskasvatusalan hallintoa, rahoitusta ja yksityisen sektorin kehittämistä, ja niillä on pyritty nostamaan kasvatus- ja opetusalan ansiotasoa sekä edistämään ammattitaitovaatimusten käyttöönottoa alalla.

Maailmanlaajuisesti tarkasteltuna varhaiskasvatus on aina omanlaisensa yhdistelmä valtiollisia, yksityisiä, yleishyödyllisiä ja vapaaehtoisvoimin toteutettavia palveluita, jotka heijastelevat kullekin maalle ominaista kansallista kontekstia ja valtion harjoittaman politiikan tavoitteita. Viime vuosina varhaiskasvatusalan laajentuminen on huomattu erityisesti niissä maissa, joissa ala on nojannut ensisijaisesti sääntelemättömän ja matalapalkkaisen yksityisen 
sektorin varaan ja joissa lasten hoito ja kasvatus on nähty perheen sisäisenä asiana ja se on järjestetty sukupuolten segregaatiolla työelämässä ja äitien osa-aikatyöllä. Näistä maista saatu kokemus osoittaa, että valtion vähäinen kiinnostus alaa kohtaan ja systemaattinen julkisen rahoituksen puuttuminen yhdistettynä ammattiyhdistysten passiivisuuteen ja kasvatustyön järjestämiseen yksityisesti kotitalouksien piirissä johtaa alan työntekijämäärän supistumiseen ja palkkatason laskuun. Negatiivista kierrettä vauhdittaa epäpätevän työvoiman ja siirtolaisten tulo alalle, mikä edelleen laskee varhaiskasvatusalan palkkatasoa ja palveluiden laatua. Feministiset tutkimukset ovat osoittaneet, että varhaiskasvatusalan palkoilla on taipumus jäädä mataliksi siksi, että alaan liitetään vahvoja mielikuvia naisellisuudesta, äitiydestä ja vanhempainrakkaudesta, joihin ei kuulu rahan ja hyödyn tavoittelu. Taloustieteilijöiden huomio kiinnittyy puolestaan varhaiskasvatustyön kalleuteen, sen tuottavuuden mittaamisen vaikeuteen sekä mahdollisuuteen nostaa alan palkkatasoa ainoastaan kuluttajan (eli tässä tapauksessa valtion ja vanhempien) kustannuksella: ratkaisevaa on, haluavatko kuluttajat käyttää suuren osan tuloistaan lasten hoitopalveluihin ja kasvatukseen.

Venäjän valtiollisella varhaiskasvatuksella on kunniakkaan historiansa ja maailmanlaajuisesti tunnustettujen saavutustensa ansiosta aihetta ylpeyteen. Mutta lähivuosina sitä kohtaa suuri murros, kun alalta lähtee sekä merkittävä osa alalla pitkän työuran tehneistä ammattilaisista että ne, jotka kouluttautuivat alalle ja aloittivat työskentelyn jo neuvostoaikana, jolloin hyvinvoinnin tasosta ja sosiaaliturvasta vastasi etupäässä valtio eivätkä työntekijät itse. Tämä ammattiryhmässä tapahtuva sukupolvenvaihdos heijastuu väistämättä sen keskeisiin indikaattoreihin. Tämän vuoksi onkin tärkeä ymmärtää, kuinka tyydyttävänä varhaiskasvatuksen ammattilaiset itse asemansa näkevät ja mitä heidän mielestään tulisi tehdä tilanteen muuttamiseksi.

Tämän kysymyksen ymmärtämiseksi on syytä tarkastella myös Venäjän yksityistä varhaiskasvatusalaa, sillä sen vauhdikasta alkuvaihetta seurasivat vakavat ongelmat ja nyt alan kehitys on käytännöllisesti katsoen pysähtynyt. Sektorien erilaisen kehityksen vuoksi yksityisen sektorin työolot poikkeavat olennaisesti valtiollisen sektorin vastaavista. Varhaiskasvatuksen työntekijöiden näkökulmasta yksityisellä sektorilla joudutaan edelleen kohtaamaan useita työntekijöiden oikeuksiin liittyviä kysymyksiä, mutta toisaalta se nähdään myös mahdollisuuksien alana, jolla saatu kokemus on otettava huomioon ja sitä on arvostettava. Millaisena yksityisellä sektorilla työskentelevät varhaiskasvatuksen ammattilaiset näkevät alan nykytilan ja sen tulevaisuuden? Eroaako ammattiryhmän rakenne valtiollisen sektorin vastaavasta ja kuinka merkittäviä ja olennaisia nämä erot ovat?

Tämän esseen aineistona toimivat valtiollisen ja yksityisen sektorin varhaiskasvatusalan ammattilaisilta vuosina 2012 ja 2014 kerätyt kysely- ja haastatteluvastaukset, jotka on esitelty tarkemmin kirjoittajan muissa julkaisuissa. On tarpeen huomauttaa, että yksityistä sektoria koskevaan tutkimukseen osallistuivat lastentarhoissa ja lasten harrastuskeskuksissa työskentelevät ammattilaiset, jotka olivat edellä mainittuna ajanjaksona Territorija obrazovanija -yhdistyksen (suom. koulutusalue) jäseniä. Tässä yhteydessä ei siis käsitellä laittomia varhaiskasvatuslaitoksia, vaan keskitytään lähinnä alalla saatuun myönteiseen kokemukseen.

\section{Varhaiskasvatustyön arvostus ja asiantuntijuuden osatekijät}

Nyky-yhteiskunnassa ei vallitse yksimielisyyttä siitä, kuka tarkalleen ottaen on asiantuntija varhaiskasvatukseen liittyvissä kysymyksissä. Vanhemmat moittivat usein varhaiskasvatusalan työntekijöitä epäammattimaisuudesta ja välinpitämättömyydestä, ja vastaavasti 
varhaiskasvatuksen työntekijöillä on tapana kyseenalaistaa vanhempien kyky ymmärtää lapsensa tarpeita ja valmius toimia lapsensa intressien mukaisesti. Vastaavanlaiset väittelyt ovat yleisiä painetuissa ja sähköisissä tiedotusvälineissä, ja tällaiset huolenaiheet nousivat esiin myös työntekijöiden haastatteluissa. Keskustelu kuvastelee varhaiskasvattajien ammattitaidon, asiantuntemuksen ja ammattipätevyyden kyseenalaistamista. Työskennelläkseen tehokkaasti varhaiskasvatuksen työntekijän on koettava, että häneen luotetaan ja että häntä pidetään ammattilaisena, alansa asiantuntijana. Toisaalta hänen on myös itse lujitettava ammatillista auktoriteettiaan sellaisella koulutustasolla, joka saa yhteiskunnan ja vanhemmat vakuuttumaan hänen asiantuntijuudestaan.

Ulkopuolisten henkilöiden myönteiset mielikuvat ammatista ja ammattiryhmän asiantuntemuksen tunnustaminen ovat tärkeitä hyvän yhteiskunnallisen aseman saavuttamiseksi ja hyvän maineen luomiseksi. Kyselyn ja haastattelujen perusteella varhaiskasvatuksen työntekijöille on tärkeää voida olla hyödyksi yhteiskunnalle ja tuntea työnsä saavan arvostusta sekä valtion että vanhempien taholta. Varhaiskasvatuksen työntekijöiden oma kokemus on kuitenkin se, ettei valtiovalta (heidän pääasiallinen työnantajansa), Venäjän kansa kokonaisuudessaan eli niin sanottu suuri yleisö (palvelujen potentiaaliset asiakkaat sekä tulevat työntekijät) eivätkä joukkotiedotusvälineet eli yhteiskunnallisen mielipiteen keskeiset muodostajat arvosta heitä riittävästi. Asiantuntijoiden haastatteluissa tilannetta kommentoidaan näin:

Tätä työtä ei juurikaan arvosteta, .... Ihmiset eivät oikein (eivät riittävästi - kirjoittajan huomautus) ymmärrä nimenomaan varhaiskasvatuksen merkitystä. (Valtiollisen lastentarhan johtaja, Samaran alue.)

Valtiovalta ei kuuntele meitä. Varhaiskasvatuksen tärkeyttä ei ymmärretä siinä määrin, kuin olisi tarpeen. Ei edes paikallishallinnon tasolla. (Valtiollisen lastentarhan johtaja, Moskova.)

On kuvaavaa, etteivät haastatellut varhaiskasvatuksen ammattilaiset olleet yksimielisiä vanhempien taholta saamastaan arvostuksesta, ja vain pieni enemmistö oli varma siitä. Ulkoisen arvostuksen ohella on tarkasteltava varhaiskasvattajien ammattiryhmän sisäisiä asiantuntijuuden osatekijöitä. Tässäkin suhteessa valtiollinen ja yksityinen sektori ovat erilaisia. Valtiollisella varhaiskasvatusalalla koetut aiemmat ja yhä jatkuvat vaikeudet näkyvät monella tapaa alan keskeisissä toiminnoissa. Alan työntekijärakenne on vinoutunut, sillä suuri osa varhaiskasvatusalan ammattilaisista on iäkkäitä ja jo pitkään alalla työskennelleitä, minkä lisäksi alan tehtäviin on tapana työllistyä korkeammalla iällä kuin aikaisemmin. Työntekijöiden kiinnostus työskennellä varhaiskasvatusalalla koko työuransa ajan on laskenut, minkä lisäksi työntekijät päättävät usein kouluttautua myöhemmin aivan toiselle alalle sen sijaan, että he tavoittelisivat korkeampaa koulutusastetta nimenomaan kasvatus- ja opetusalalla. Näistä syistä valtiollisen sektorin lastentarhoihin eivät niinkään hakeudu toisen tai kolmannen asteen oppilaitoksista vastikään valmistuneet nuoret aikuiset, vaan pikemminkin keski-ikäiset naiset, joilla ei ole kasvatusalan koulutusta. Huomionarvoista on, että valtiovalta pyrkii muuttamaan tämän tendenssin suuntaa ja on hiljattain asettanut varhaiskasvatusalan ammattipätevyyden vaatimukseksi kasvatus- ja opetusalan korkeakoulututkinnon. Alan henkilöstöä kuvaavat tilastot eivät kuitenkaan osoita tilanteen muuttuneen parempaan suuntaan. Yksityiseltä sektorilta saadut tiedot osoittavat sektoreiden välillä vallitsevan perustavanlaatuisen eron: yksityisen sektorin työntekijöistä vain harva on iäkäs tai työskennellyt pitkään alalla. Lisäksi kaikenikäiset työntekijät ovat kiinnostuneita hankkimaan korkeakoulutuksen, mikä on osoitus 
sellaisesta kulttuurisesta ja symbolisesta pääomasta, joka voi pitkällä aikavälillä parantaa ammattiryhmän ansiotasoa ja nostaa sen arvostusta.

Sekä valtiollisen että yksityisen sektorin kasvatus- ja opetusalan työntekijät ovat yhtä mieltä siitä, että varhaiskasvatuksen työntekijöiden arvostuksen lisäämisen kannalta keskeistä on sekä ammatin ulkoiseen kuvaan että alakohtaisiin ammattitaitovaatimuksiin vaikuttaminen. Kun varhaiskasvatuksen ammattilaisilta kysyttiin, miten alan työntekijöiden ammattiasemaa voitaisiin parantaa, esille nousivat vanhempien valistaminen (jotta varhaiskasvatuksen ammattilaisiin luotettaisiin enemmän ja heitä arvostettaisiin), suurelle yleisölle levitettävä tieto varhaiskasvatustyön tärkeydestä ja sen haasteista (esimerkiksi elokuvien, lehdistön ja television välityksellä) sekä pätevyysvaatimusten tiukentaminen.

\section{Varhaiskasvatusalan työolot ja ammattilaisten yhteishenki}

Ammattiensosiologiassa pidetään odotuksen mukaisena sellaista tilannetta, jossa erityisosaamista ja koulutusta vaativassa työssä työskentelevät ammattilaiset itse määrittelevät keskeiset työoloihinsa vaikuttavat tekijät. Nykymaailmassa ne ammatit, joiden työnkuvaan kuuluu sosiaalipalvelujen tarjoaminen suurelle ihmisjoukolle ja ihmisten hyvinvoinnista huolehtiminen, ovat yhä enemmän riippuvaisia pääasiallisen työnantajan rooliin astuvasta valtiosta. Tällaisessa tilanteessa on suorastaan välttämätöntä, että ammattilaiset voivat ilmaista mielipiteensä sellaisissa valtion päätösvaltaan kuuluvissa asioissa, jotka liittyvät heidän mahdollisuuksiinsa tehdä työnsä tehokkaasti.

Varhaiskasvatuksen työntekijöiden tehokkaan työnteon sekä suunnittelu- ja soveltamistaitoja vaativien työtehtävien lisääntymisen tai vähenemisen kannalta merkityksellisiä työoloihin vaikuttavia tekijöitä ovat muun muassa hoitoryhmien koko, varhaiskasvatussuunnitelmien käyttäminen tai niiden puuttuminen sekä niiden sisältö. Tässäkin yhteydessä valtiolliselle ja yksityiselle sektorille ominaisissa tendensseissä on havaittavissa eroavaisuuksia. Valtiollisen sektorin varhaiskasvattajat kertovat työkuormansa lisääntyneen kasvaneiden ryhmäkokojen, lisääntyneiden paperitöiden, puuttuvien varhaiskasvatussuunnitelmien ja kasvatusalan tehtäviin erikoistuneiden työtoverien vähyyden vuoksi. Yksityisellä sektorilla tilanne on tyypillisesti aivan päinvastainen, mikä entisestään voimistaa sektorien välisiä eroja sekä ammattiryhmän jäsenten välillä tapahtuvaa eriytymistä. Ammattilaiset kommentoivat tilannetta haastatteluissa seuraavasti:

Todella paljon turhia ... selontekoja, jotka toistavat itseään, me suorastaan hukumme papereihin. ... Kyllä ihmiset muutenkin tekevät töitä, lasten kanssa tehtävä työ vaatii itsessään valtavasti voimia. (Samaran alue.)

Viime aikoina kunnallisten lastentarhojen ryhmäkoot ovat olleet todella suuria. Hoitopaikkoja ei ole tarpeeksi ja olemme saaneet taistella saavutettavuuden puolesta. ... Ryhmät ovat isoja ja lastentarhat täpötäynnä. Tehokas työ on fyysinen mahdottomuus. ... Lapset kaipaavat toisenlaisia olosuhteita. (Kunnallinen varhaiskasvatuslaitos, Samara.)

Yksityisen varhaiskasvatusalan etuna on se, että ... lapsia on vähemmän. Meillä ryhmästä huolehtii kaksi työntekijää, ei yksi kuten kunnan laitoksissa. ... Valtava etu kasvatusprosessin kannalta. ... Jos kunnallisella puolella vanhemmille jää paljon tehtävää kotona, niin meillä tätä ongelmaa ei ole. (Yksityinen varhaiskasvatuslaitos, Samara.) 
Valtiollisella ja yksityisellä sektorilla työskentelevien varhaiskasvattajien välillä on eroa myös siinä, millaisina he näkevät urakehityksensä. Yksityisen sektorin työntekijät pitävät varhaiskasvatusalalla työskentelyä lähinnä eräänlaisena välivaiheena, jonka ei ole tarkoitus jatkua koko työuran ajan. Tähän vaikuttaa omalta osaltaan nuoren työvoiman suuri kysyntä, sekä toisaalta ammattilaisten suuntautuminen urallaan etenemiseen. Yksityisen sektorin työntekijöitä kiinnostaa työskentely yksityisinä palveluntarjoajina tai toiminta varhaiskasvatusalan johtotehtävissä. Valtiollisen sektorin ammattilaisten urakäyttäytymistä luonnehtii sen sijaan ennen kaikkea pyrkimys vakauteen: he tavoittelevat sosiaalisesti turvattua asemaa, mikä selittyy osaltaan aiemmin mainitulla työntekijöiden ikään ja pätevyystasoon liittyvällä epätasapainolla.

Tyytymättömyys alan nykytilanteeseen lisää ymmärrystä muutoksen tarpeesta. Mutta kun pidetään mielessä, että Venäjän varhaiskasvatusala kehittyi laajamittaisesti neuvostoaikana, jolloin valtiolla oli hallitseva asema taloudessa, hallinnossa ja politiikassa, on ymmärrettävää, että varhaiskasvatuksen ammattilaiset pitävät varhaiskasvatusalan uudistamiseen liittyviä tavoitteenasetteluja yhtä lailla sekä valtion että oman ammattiryhmänsä tehtävänä. Vaikka valtaosa varhaiskasvatuksen työntekijöistä on tyytymättömiä työoloihinsa valtiollisella sektorilla ja kuvaa ammattiryhmäänsä sosiaalisesti suojattomaksi, eivät he kuitenkaan ole valmiita ryhtymään valtion aktiivisiksi yhteistyökumppaneiksi ja vaikuttamaan valtion tekemiin alaansa koskeviin päätöksiin.

\section{Varhaiskasvatuksen ammattilaisten tulotasosta}

Varhaiskasvatusalalla työskentelevien asiantuntijoiden ansiot ovat perinteisesti olleet melko matalat. Ennen Venäjän vallankumousta sekä neuvostoaikana ja sen jälkeisenä ajanjaksona varhaiskasvatuksen ammattilaisten palkkataso oli tehdastyöläisten palkkatasoa matalampi. Presidentin 7. toukokuuta vuonna 2012 antaman erityisen asetuksen nojalla kasvatus- ja opetusalan työntekijöiden keskimääräisen kuukausipalkan oli määrä nousta aluekohtaisen keskipalkan tasolle. On vaikeaa arvioida, missä määrin kasvatus- ja opetusalalla työskentelevien henkilöiden elintaso todellisuudessa on muuttunut, mutta heidän omien sanojensa mukaan alhainen palkkataso on yksi ammatin suurimmista ajankohtaisista ongelmista. Puolet haastatelluista kertoi, että he ovat aiemmin toimineet väliaikaisesti muussa ammatissa, ja useimmilla tämä johtui nimenomaan mahdollisuudesta ansaita paremmin muualla kuin varhaiskasvatusalalla. Asiantuntijoiden haastatteluissa tilannetta luonnehditaan näin:

\footnotetext{
Minua ärsyttää suuresti se, että kaikki sanovat oikeat asiat, että lapsuus on elämän tärkeintä aikaa. Lapsuus luo elämälle perustan, kaikki ihmisen ongelmat juontuvat lapsuudesta, lastentarhoissa kasvatetaan ihmisiä, joiden tulee pärjätä hyvin koulussa, opinnoissa ja yhteiskunnassa... Mutta vastaavasti myös täällä työskentelevien ihmisten tulisi menestyä ja heidän tulisi saada kunnollista palkkaa. Kyllähän tästä asiasta paljon puhutaan, muttei juuri mitään saada aikaiseksi. Toki jotakin muutosta tapahtuu, muttei riittävästi. Toisinaan varhaiskasvatusalalla työskentelevä henkilö saattaa jopa olla haluton kertomaan, että hän työskentelee juuri varhaiskasvatuksessa, vaikka hänellä onkin kaksi korkeakoulututkintoa. (Informantti, kunnallinen varhaiskasvatuslaitos.)
}

On ymmärrettävää, että yksityisellä sektorilla vaaditaan palkkojen nostamista, sillä palkkatulot muodostavat työntekijöiden pääsääntöisen tulonlähteen ja toimivat korvauksena tehdystä 
työstä. Tämän lisäksi yksityisen sektorin työntekijät vaativat enemmän tilaisuuksia hankkia lisäansioita työpaikallaan, mikä ei ole tyypillistä valtiollisella sektorilla, jolla ensisijaista on palveluiden hyvä saavutettavuus vanhempien sosioekonomisesta asemasta riippumatta.

Tässä yhteydessä on kiinnostavaa selvittää, miten voitaisiin poistaa ammattikontakteissa ilmenevää sosiaalista eriarvoisuutta, jossa voi esiintyä vaihtelua riippuen siitä, millaisena varhaiskasvatuksen ammattilaiset itse näkevät oman yhteiskunnallisen asemansa. Arvioitaessa suuri- ja pienituloisten osoittamaa arvostusta kasvatus- ja opetusalan työntekijöitä kohtaan varhaiskasvatuksen ammattilaiset olivat yhtä mieltä siitä, että pienituloiset arvostavat heitä enemmän kuin suurituloiset, ja erityisen yleinen tämä näkemys oli valtiollisen sektorin työntekijöillä. Valtiollisella sektorilla työskentelevien varhaiskasvatuksen ammattilaisten mielikuvat ammattiryhmien statuseroista ilmenivät ammatin arvostuksen puutteena ja alan uudistamista seuranneena palkkatason muutoksena. Sen sijaan itsekunnioituksen määrässä statusero ei näkynyt yhtä selkeästi. Yksityisellä varhaiskasvatusalalla työskentelevien ammattilaisten arviot sekä omasta yhteiskunnallisesta asemastaan että itsekunnioituksestaan ovat korkeammat kuin valtiollisen sektorin työntekijöillä. He ovat myös yleisesti ottaen sitä mieltä, että yhteiskunnallista eriarvoisuutta voidaan tasata ammatin kautta saatavien kontaktien kautta. Tähän voi olla syynä se, että he ovat työnsä kautta olleet päivittäin tekemisissä yksityisen sektorin pääsääntöisten asiakkaiden eli suurituloisten ammattiryhmiin kuuluvien kanssa.

\section{Lopuksi}

Venäjän varhaiskasvatusalan ammattilaiset kohtaavat edelleen - huolimatta valtiovallan yrityksistä muuttaa tilannetta - alan työntekijärakenteeseen sekä ammattinsa arvostukseen liittyviä ongelmia. He myös yhdistävät nämä ongelman alalle ominaiseen tulotasoon. Kasvatus- ja opetusalan ammattilaisen on tärkeää voida kokea, että hänen ja työnantajan, eli tässä tapauksessa valtion ja yhteiskunnan, suhteet perustuvat luottamukseen ja molemminpuoliseen kunnioitukseen ja että ne vahvistavat ammatin asemaa, johon kuuluu kiinteänä osana työstä saatava palkka. On syytä mainita, etteivät venäläisten kasvatus- ja opetusalan työntekijöiden arviot ammattiinsa kohdistuvasta ulkoisesta arvostuksesta ole poikkeuksellisia. Tässä suhteessa merkittävinä voidaan pitää Euroopan unionin perusopetuksen opettajien yhteisön tekemän tutkimuksen tuloksia, joiden mukaan palkkatasolla on vaikutusta opettajien tulkintaan ammattinsa saamasta ulkoisesta arvostuksesta. Aihetta koskevat kysymykset ovat näin ollen edelleen ajankohtaisia.

Korporatiivista valtaa ja solidaarisuutta edustavien instituutioiden heikkous on erityisen ajankohtainen aihe valtiollisella sektorilla, jolle on ominaista työntekijöiden tyytymättömyys alan työoloihin. Ne tekevät keskeisten työtehtävien asianmukaisen suorittamisen haastavaksi. Valtiovallan takaaman vakauden kääntöpuolena on ollut ja on yhä ammattijärjestöjen ja -yhteisöjen passiivisuus, mikä on seurausta siitä, että valtio on toiminut varhaiskasvatusalan työmarkkinoilla pääasiallisena työnantajana. Kaiken kaikkiaan kyseistä ammattiryhmää luonnehtii varsin laaja joukko erinäisiä ongelmia, joiden ratkaisu vaatii koko ammattiyhteisön järjestelmällistä ponnistelua. Ammattikunnan edustajat olisivat valmiita ottamaan osaa alansa tulevaisuuden suunnitteluun, mutta he eivät saa tähän tukea ammattikunnan mielipidettä ajavilta instituutioilta. Näitä instituutioita ei kuitenkaan voi korvata pelkästään sokealla luottamuksella valtiovaltaan tai siirtymisellä harmaille markkinoille. Ongelmat eivät uhkaa varhaiskasvatuksen ammattilaisten olemassaoloa ammattiryhmänä, mutta hyvin organisoidulla yksityisellä sektorilla saatu kokemus on osoitus siitä, että jos työoloihin vaikuttaviin 
tekijöihin kiinnitetään riittävästi huomiota ja alan ansiotasoa nostetaan keskituloisten tasolle nopeammin, ala voi sille asetettujen korkeiden ammattipätevyysvaatimusten ansiosta alkaa vetää puoleensa myös nuorempaa työvoimaa.

\section{Kääntänyt: Anneli Hanhisalo}

\section{Lähteet}

Kolesnikova J. M. \& Mitrohina J. V. (2017), Vospitateli i utšitelja ob uslovijah truda i organizatsionnoi podderžke. - Vestnik Instituta sotsiologii 20:1, 13-34. DOI: 10.19181/vis.2017.20.1.443

Kolesnikova J. M. (2016), Pedagogi tšastnogo i gosudarstvennogo doškolnogo obrazovanija: status gruppy i perspektivy razvitija. - Sotsiologitšeski žurnal 22:1, 114-132. DOI: https://doi. org/10.19181/socjour.2016.22.1.3919

Kolesnikova J. M. (2018), Pedagogi doškolnogo obrazovanija: vosprijatie reputatsii v SMI i problemy modernizatsii informatsionnoi politiki. - Professionalnye gruppy v modernizirujuštšsemsja rossijskom obštšestve. Red. Valeri A. Mansurov. Moskova: FNISTS RAN, 109-122. http://www. isras.ru/publ.html?id=6817

Blau D. (2001), The child care problem: an economic analysis. New York: Russell Sage

Cleveland G. H., Hyatt D. E. (2002), Child Care Workers' Wages: New Evidence on Returns to Education, Experience, Job Tenure and Auspice. Child Care and Preschool Development in Europe: Institutional Perspectives Journal of Population Economics, 15:3, 575-597. http://link.springer. com/article/10.1007/s001480100106

Competence Requirements in Early Childhood Education and Care. A study for European Commission Directorate-General for Education and Culture. Final Report (2011), University of East London, Cass School of Education and University of Ghent, Department for Social Welfare Studies. https:// files.eric.ed.gov/fulltext/ED534599.pdf (Tarkistettu 15.4.2018).

England P. (2005), Emerging theories of care. - Annual Review of Sociology, 31:1, 381-399. http:// www.annualreviews.org/doi/abs/10.1146/annurev.soc.31.041304.122317

European Commission/EACEA/Eurydice The Teaching Profession in Europe: Practices, Perceptions, and Policies. Eurydice Report. Luxembourg: Publications Office of the European Union. https:// doi.org/10.2797/031792, 2015.

Folbre N. (2006), Demanding Quality: Worker/Consumer Coalitions and "high road" strategies in the care sector. Politics \& Society, 34:1, 11-32. http://pas.sagepub.com/content/34/1/11.abstract

Fuller B., Strath A. (2001), The Child-Care and Preschool Workforce: Demographics, Earnings, and Unequal Distribution. Educational Evaluation and Policy Analysis, 23:1, 37-55. http://epa.sagepub. com/content/23/1/37.abstract

Grimshaw D., Rubery J. (2007), Undervaluing women's work. Manchester: Equal Opportunities Commission.

Laere K.V., Peeters J., Vandenbroeck M. (2012), The Education and Care Divide: the role of the early childhood workforce in 15 European countries. - European Journal of Education, 47:4, 527-541. http://onlinelibrary.wiley.com/doi/10.1111/ejed.12006/abstract

Lewis J. (1992), Gender and the Development of Welfare Regimes. - Journal of European Social Policy, 2:3, 159-173. http://esp.sagepub.com/content/2/3/159.abstract

Scheiwe K., Willekens H. (Eds) (2009), Child Care and Preschool Development in Europe: Institutional Perspectives. Houndmills: Palgrave MacMillan. 